\title{
Pemodelan Kekambuhan Pasien Kanker Serviks di RSUD dr. Soetomo Surabaya Menggunakan Regresi Cox Extended
}

\author{
Tannassia Winda Adharina, dan Santi Wulan Purnami \\ Departemen Statistika, Fakultas MIPA, Institut Teknologi Sepuluh Nopember (ITS) \\ e-mail:winda9595@gmail.com, santiwulan08@gmail.com
}

\begin{abstract}
Abstrak-Kanker leher rahim atau lebih sering disebut kanker serviks merupakan kanker yang tumbuh di dalam leher rahim/serviks yang terdapat didalam organ bagian reproduksi pada tubuh wanita. Penyakit ini menyebabkan kematian dan lebih dari $85 \%$ terjadi di Negara berkembang di seluruh dunia. Analisis survival merupakan salah satu metode yang dapat digunakan untuk menganalisis data berdasarkan waktu. Pada penelitian ini membahas mengenai kekambuhan pasien kanker serviks di RSUD dr. Soetomo Surabaya menggunakan pemodelan regresi Cox Extended. Berdasarkan hasil analisis, probabilitas pasien kanker serviks di RSUD dr. Soetomo selama dua tahun penelitian yang tidak mengalami kambuh pertama kali dibawah 50\%. Pasien kanker serviks cenderung mengalami penurunan kondisi setelah dua bulan pertama. Variabel yang tidak memenuhi asumsi proportional hazard adalah status operasi. Variabel yang signifikan mempengaruhi kekambuhan pasien kanker serviks di RSUD dr. Soetomo adalah status operasi. Model terbaik berdasarkan kriteria AIC terkecil adalah pemodelan regresi cox extended menggunakan fungsi waktu. Laju kekambuhan pasien kanker serviks yang melakukan tindakan operasi memiliki laju kekambuhan yang berbeda-beda karena bergantung waktu.
\end{abstract}

Kata Kunci-Analisis Survival Kanker Serviks dan Uji Proportional Hazard.

\section{PENDAHULUAN}

$\mathrm{K}$ ANKER serviks merupakan salah satu penyakit kanker yang cukup sering diderita oleh wanita di Indonesia. Kasus kanker yang terletak di leher rahim tersebut menempati peringkat teratas didunia yang menyebabkan kematian wanita dan lebih dari $85 \%$ terjadi di Negara berkembang. Sebanyak 270.000 wanita meninggal dunia setiap tahunnya karena menderita kanker serviks [1]. Sebanyak 20 hingga 25 wanita di Indonesia meninggal karena menderita kanker serviks tersebut [2]. Perlunya mendeteksi kanker pada stadium dini merupakan cara yang cukup efektif karena sebesar $85 \%$ mampu mengurangi angka kematian dan angka kejadian yang disebabkan oleh kanker serviks [2].

Suatu negara dianggap telah berhasil dalam menangani kasus kanker serviks apabila negara tersebut mampu meningkatkan probabilitas ketahanan hidup pasien yang mengalami kanker serviks [3]. Terdapat beberapa faktor yang mempengaruhi ketahananan hidup pasien kanker serviks berdasarkan penelitian yang telah dilakukan yaitu usia sebagai faktor yang mempengaruhi ketahanan hidup pasien, stadium kanker serviks sebagai faktor yang berhubugan dengan ketahanan hidup pasien [4], stadium dan kelengkapan pengobatan [5], anemia dan kelengkapan pengobatan juga sebagai faktor yang berpengaruh terhadap ketahanan hidup pasien [6] dan komplikasi merupakan faktor yang berpengaruh terhadap ketahanan hidup pasien kanker serviks [7].

Analisis Survival merupakan salah satu metode yang dapat digunakan untuk menganalisis kekambuhan pasien kanker serviks berdasarkan waktu hingga terjadinya event. Pengolahan data survival biasanya menggunakan asumsi cox proportional hazard dimana suatu individu akan mengalami kejadian pada suatu waktu tertentu dinyatakan dengan hazard rate [8]. Apabila asumsi proportional hazard tidak terpenuhi metode yang sering digunakan adalah dengan menggunakan Regresi Cox Stratifikasi atau Regresi Cox Extended. Penelitian sebelumnya stadium IV dan jenis pengobatan berpengaruh signifikan pada data survival kanker serviks di RSUD dr. Soetomo Surabaya [9]. Berdasarkan permasalahan tersebut maka pada penelitian kali ini dilakukan pemodelan kekambuhan pasien kanker serviks di RSUD dr. Soetomo Surabaya menggunakan Regresi Cox Extended.

\section{TINJAUAN PUSTAKA}

\section{A. Analisis Survival}

Analisis survival telah menjadi metode yang penting untuk menganalisis data mengenai waktu antar kejadian (time to event data) atau menganalisis data yang berhubungan dengan waktu[10]. Kejadian didalam analisis survival dibagi menjadi dua kejadian dimana kejadian tersebut ditentukan oleh peneliti. Kejadian pertama yaitu (failure event) merupakan kejadian seperti kegagalan, kematian, kambuhnya suatu penyakit, respon dari suatu percobaan, atau peristiwa lain yang dipilih. Selain failure event pada analisis survival juga terdapat kejadian positif seperti kelahiran, kelulusan sekolah, kesembuhan dari suatu penyakit. Analisis survival secara umum memiliki tiga tujuan yaitu

a. Mengestimasi dan menginterpretasikan survivor function dan/atau hazard function dari data survival.

b. Membandingkan survivor function dan/atau hazard function.

c. Mengetahui pengaruh dari variabel prediktor terhadap waktu survival.

Pada analisis Survival sering ditemukan istilah penyensoran. Penyensoran terjadi apabila data tidak dapat diamati secara lengkap karena individu selama penelitian hilang atau mengundurkan diri atau sampai akhir penelitian subjek tersebut belum mengalami kejadian tertentu, sedangkan data yang tidak tersensor dapat diamati secara lengkap sampai penelitian berakhir. 


\section{B. Kurva Kaplan-Meier dan Uji Log-Rank}

Kurva Kaplan-Meier digunakan untuk menaksir fungsi survival [10]. Apabila probabilitas dari Kaplan-Meier adalah $\left.\widehat{S(} t_{(j)}\right)$ maka perasamaan umumnya adalah sebagai berikut.

$$
\hat{S}\left(t_{(j)}\right)=\prod_{i=1}^{j} \hat{P} r\left(T>t_{(i)} \mid T \geq t_{(i)}\right)
$$

Selain mengetahui kurva Kaplan-Meier untuk membandingkan kurva survival dalam kelompok yang berbeda terdapat pula uji Uji Log-Rank yang merupakan uji statistik nonparametrik. Berikut merupakan statistik uji LogRank

$$
X_{\text {hitung }}=\sum_{i=1}^{G} \frac{\left(O_{i}-E_{i}\right)^{2}}{E_{i}}
$$

\section{Pengujian Asumsi Proportional Hazard}

Asumsi proportional hazard merupakan suatu kondisi dimana nilai hazard ratio bersifat konstan [10]. Terdapat tiga metode untuk memenuhi asumsi cox proportional hazard yaitu sebagai berikut.

1) Grafik

Grafik yang digunakan dalam pengujian asumsi $\mathrm{PH}$ yaitu plot kurva Kaplan-Meier pengamatan (observed) dan prediksi (expected) dari model Cox PH dan plot $-\ln (-\ln S(t))$ terhadap waktu survival. Berikut ini adalah gambar plot observed versus expected dan plot survival $-\ln (-\ln S(t))$.

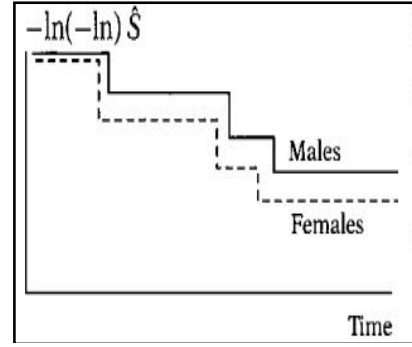

(a)

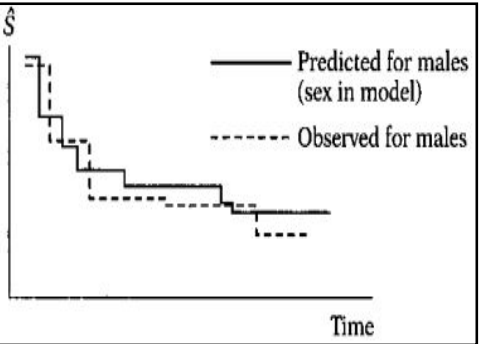

(b)
Gambar 1. Ilustrasi Grafik untuk Asumsi PH.

Pada gambar (a), asumsi PH terpenuhi apabila garis antar kategori sejajar sedangkan untuk gambar (b) asumsi proportional hazard terpenuhi apabila kurva survival pengamatan (observed) dan prediksi (expexted) saling berhimpit.

2) Uji Goodness of Fit

Berikut ini adalah langkah-langkah pengujian asumsi proportional hazard dengan uji goodness of fit (GOF).

a. Mendapatkan residual schoenfeld menggunakan model Cox Proportional Hazard untuk setiap variabel prediktor. Residual schoenfeld ada pada setiap variabel prediktor pada model dan kejadian yang dialami oleh suatu objek.

b. Membuat variabel rank waktu survival yang telah diurutkan berdasarkan waktu survival mulai dari individu yang mengalami event pertama kali.

c. Melakukan pengujian korelasi antara variabel residual schoenfeld dan rank waktu survival.
Residual schoenfeld dari variabel prediktor ke-k dari individu yang mengalami event pada waktu $t_{j}$ dapat dirumuskan sebagai $P R_{k j}=x_{k j}-E\left\langle x_{k j} \mid R\left(t_{(j)}\right)\right\rangle$ dimana

$$
E\left\langle x_{k j} \mid R\left(t_{(j)}\right)\right\rangle=\frac{\sum_{l \in R\left(t_{(j)}\right)} x_{k j} \exp \left(\boldsymbol{\beta}^{\prime} \boldsymbol{x}_{\boldsymbol{l}}\right)}{\sum_{l \in R\left(t_{(j)}\right)} \exp \left(\boldsymbol{\beta}^{\prime} \boldsymbol{x}_{\boldsymbol{l}}\right)}
$$

Selanjutnya adalah melakukan pengujian antara residual schoenfeld dengan rank waktu survival untuk setiap variabel digunakan koefisien korelasi pearson sebagai berikut

$$
r_{R T, P R_{k}}=\frac{\sum_{j=1}^{n}\left(P R_{k j}-\overline{P R}_{k j}\right)\left(R T_{j}-\overline{R T}_{j}\right)}{\sqrt{\sum_{j=1}^{n}\left(P R_{k j}-\overline{P R}_{k j}\right)^{2}} \sqrt{\sum_{j=1}^{n}\left(R T_{j}-\overline{R T}_{j}\right)^{2}}}
$$

dengan hipotesis sebagai berikut

$H_{0}: \rho=0$

$H_{1}: \rho \neq 0$

Statistik uji

$$
t_{h i t}=\frac{r_{R T, P R_{k}} \sqrt{n-2}}{\sqrt{1-r_{R T, P R_{k}}^{2}}}
$$

Tolak $\mathrm{H}_{0}$ jika $\left|t_{h i t}\right|>t \propto / 2, n-2$ atau $p$-value kurang dari $\alpha$

3) Pendekatan Variabel Time Dependent

Variabel time dependent pada survival menggunakan fungsi waktu dengan hipotesis sebagai berikut

Hipotesis:

$H_{0}: \delta_{1}=\delta_{2}=\cdots=\delta_{q}=0$

$H_{1}$ : minimal terdapat satu $\delta_{m} \neq 0 ; \quad m=1,2,3, \ldots, q$

Koefisien regresi dari $\mathrm{m}$ variabel prediktor yang tidak memenuhi asumsi proportional hazard diwakili oleh $\delta_{\mathrm{m}}$. Sehingga statistik uji yang digunakan menggunakan likelihood ratio sebagai berikut

$L R=-2 \ln L_{P H \text { model }}-\left(-2 \ln L_{\text {ext.cox model }}\right) \sim X_{p}{ }^{2}$

\section{Model Cox Extended}

Jika terdapat variabel prediktor yang bergantung pada waktu sehingga asumsi proportional hazard tidak dipenuhi maka dapat menggunakan metode regresi Cox Extended. Definisi variabel yang nilainya bisa berubah setiap saat merupakan variabel yang bergantung terhadap waktu [10]. Apabila terdapat $\mathrm{q}$ variabel prediktor yang tidak memenuhi asumsi proportional hazard, maka sebanyak q variabel yang harus dilakukan untuk membentuk model cox extended yaitu sebagai berikut

$h(t, x(t))=h_{0}(t) \exp \left[\sum_{k=1}^{p} \beta_{k} x_{k}+\sum_{m=1}^{q} \delta_{m} x_{m} g_{m}(t)\right]$

\section{E. Kanker Serviks}

Kanker leher rahim atau lebih sering disebut kanker serviks merupakan kanker yang tumbuh di dalam leher Rahim/serviks yang terdapat didalam organ bagian reproduksi pada tubuh wanita. Kanker serviks menempati urutan ketiga setelah kanker ovarium dan kanker endometrium [11].

Terdapat beberapa faktor yang mempengaruhi ketahanan kekambuhan pasien kanker serviks [12] yaitu usia, status sosial ekonomi, adanya komplikasi [13], operasi dan kemoterapi [14]. Penelitian sebelumnya [9] memberikan hasil bahwa stadium IV dan jens pengobatan merupakan faktor 
yang signifikan mempengaruhi ketahanan hidup penderita kanker serviks di RSUD dr. Soetomo Surabaya dan probabilitas ketahanan hidup 1 tahun penderita kanker serviks di RSUD dr. Soetomo Surabaya.

\section{METODOLOGI PENELITIAN}

\section{A. Sumber Data}

Sumber data yang digunakan adalah data sekunder berupa data rekam medis pasien kanker serviks di Rumah Sakit Umum Daerah dr. Soetomo Surabaya selama dua tahun yaitu dimulai dari tanggal 1 Januari 2015 hingga 29 November 2016.

\section{B. Variabel Penelitian}

Variabel yang digunakan pada penelitian ini adalah sebagai berikut

Tabel 1.

Variabel Penelitian

\begin{tabular}{|c|c|c|c|c|}
\hline No & Variabel & $\begin{array}{c}\text { Nama } \\
\text { Variabel } \\
\end{array}$ & Keterangan & Skala \\
\hline 1 & $\mathrm{~T}$ & $\begin{array}{l}\text { Waktu } \\
\text { Survival }\end{array}$ & $\begin{array}{l}\text { Waktu Pasien kanker } \\
\text { Serviks menjalani } \\
\text { perawatan hingga } \\
\text { dinyatakan kambuh atau } \\
\text { meninggal atau berhenti } \\
\text { /pindah pengobatan selama } \\
\text { penelitian berlangsung }\end{array}$ & Rasio \\
\hline 2 & d & Status Pasien & $\begin{array}{l}0=\text { Pasien kanker serviks } \\
\text { pindah pengobatan atau } \\
\text { meninggal(tersensor) } \\
1=\text { Pasien datang kembali } \\
\text { menjalani rawat } \\
\text { inap/kambuh(event) }\end{array}$ & Nominal \\
\hline 3 & $\mathrm{X}_{1}$ & Usia & Usia pasien kanker serviks & Rasio \\
\hline 4 & $\mathrm{X}_{2}$ & Kemoterapi & $\begin{array}{l}0=\text { Tidak } \\
1=\text { Ya }\end{array}$ & Nominal \\
\hline 5 & $\mathrm{X}_{3}$ & Komplikasi & $\begin{array}{l}0=\text { Tidak } \\
1=\text { Ya }\end{array}$ & Nominal \\
\hline 6 & $\mathrm{X}_{4}$ & $\begin{array}{l}\text { Penyakit } \\
\text { Penyerta }\end{array}$ & $\begin{array}{l}0=\text { Tidak (Sebagai penyakit } \\
\text { utama) } \\
1=\text { Ya (Sebagai penyakit } \\
\text { penyerta) }\end{array}$ & Nominal \\
\hline 7 & $\mathrm{X}_{5}$ & $\begin{array}{l}\text { Status } \\
\text { Anemia }\end{array}$ & $\begin{array}{l}0=\text { Tidak } \\
1=\text { Ya }\end{array}$ & Nominal \\
\hline 8 & $\mathrm{X}_{6}$ & StatusOperasi & $\begin{array}{l}0=\text { Tidak } \\
1=\text { Ya }\end{array}$ & Nominal \\
\hline
\end{tabular}

Skema survival pada penelitian kali ini adalah sebagai berikut

1. Kejadian yang diteliti adalah kondisi pada saat pasien kanker serviks selama menjalani rawat inap kembali atau kambuh di RSUD dr. Soetomo Surabaya

2. Skala pengukuran yang digunakan adalah dalam satuan hari

3. Tipe sensor pada penelitian ini adalah sensor kanan dimana kondisi pasien dinyatakan meninggal atau pindah pengobatan hingga penelitian berakhir yaitu hingga tanggal 29 November 2016.

\section{Tahapan Analisis Data}

Berikut ini adalah tahapan yang dilakukan dalam analisis data pada penelitian kali ini:

1. Mendapatkan kurva survival pasien kanker serviks dan menguji perbedaan kurva survival dengan uji Log-Rank
2. Menguji asumsi proportional hazard pada variabel prediktor yang diduga mempengaruhi kekambuhan pasien kanker serviks dengan tiga pendekatan grafik, goodness of fit dan time dependent.

3. Memodelkan kekambuhan pasien kanker serviks menggunakan regresi cox extended dengan fungsi waktu dan fungsi Heaviside.

4. Pemilihan model terbaik dengan kriteria nilai AIC terkecil

5. Interpretasi model regresi cox extended.

\section{ANALISIS DAN PEMBAHASAN}

\section{A. Kurva Kaplan-Meier dan Uji Log-rank}

Kurva survival Kaplan-Meier yaitu suatu kurva yang menggambarkan hubungan antara estimasi fungsi survival dengan waktu survival pasien kanker serviks yang kambuh pertama kali berdasarkan enam faktor yang diduga berpengaruh terhadap kekambuhan pasien kanker serviks. 1) Faktor Usia

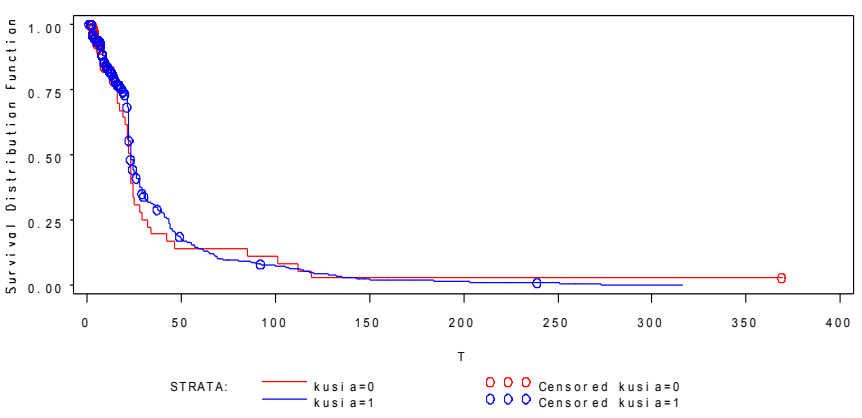

Gambar 2. Kurva Survival Faktor Usia.

Berdasarkan kurva gambar diatas warna merah menunjukkan kurva survival pasien kanker serviks dalam kelompok usia muda sedangkan warna biru masuk kedalam kelompok usia dewasa. Kedua kurva dalam kelompok yang berbeda tersebut berhimpit dari awal hingga penelitian berakhir. Sehingga pasien kanker serviks usia muda dengan usia dewasa relatif memiliki probabilitas kambuh yang sama yaitu dibawah $50 \%$.

2) Faktor Kemoterapi

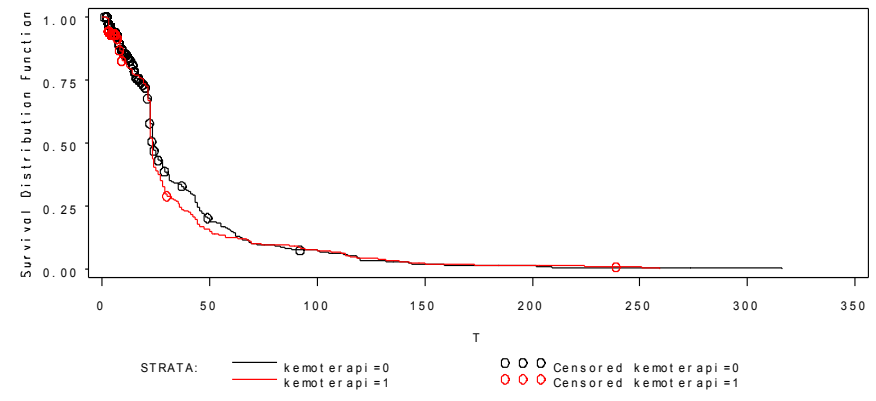

Gambar 3. Kurva Survival Faktor Kemoterapi.

Warna hitam menunjukkan kurva survival pasien kanker serviks dalam kategori tidak melakkukan kemoterapi sedangkan warna merah masuk kedalam kategori pasien yang melakukan kemoterapi. Kedua kurva dalam kelompok yang berbeda tersebut berhimpit dari awal hingga penelitian 
berakhir. Sehingga pasien kanker serviks yang melakukan kemoterapi maupun tidak melakukan kemoterapi relatif memiliki probabilitas kambuh yang sama yaitu dibawah $50 \%$.

\section{3) Faktor Komplikasi}

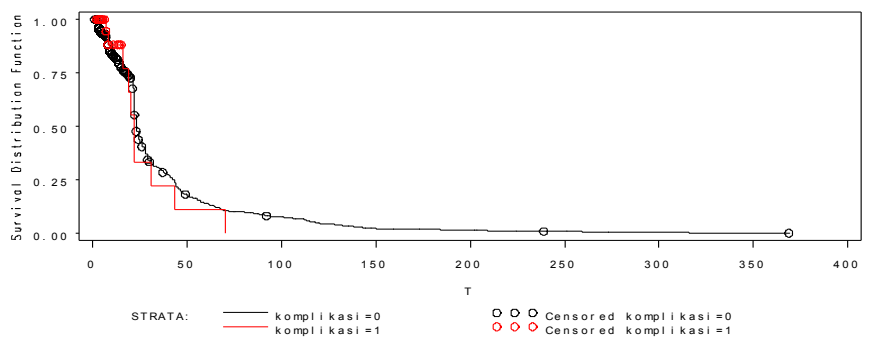

Gambar 4. Kurva Survival Faktor Komplikasi.

Gambar diatas memperlihatkan kurva pasien kanker serviks berwarna hitam yang tidak mengalami komplikasi memiliki probabilitas untuk kambuh selama dua tahun berhimpit dengan kurva pasien dengan kanker serviks yang mengalami komplikasi yang berwarna merah, dimana kedua kelompok tersebut masih memiliki probabilitas kambuh yang cenderung sama yaitu di bawah 50\%.

4) Faktor Penyakit Penyerta

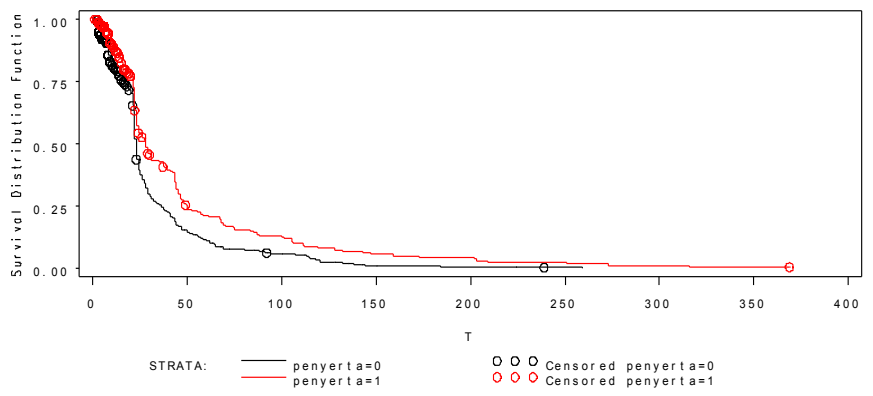

Gambar 5. Kurva Survival Faktor Penyakit Penyerta.

Gambar diatas memperlihatkan bahwa pasien yang mengidap kanker serviks sebagai penyakit penyerta yang ditunjukkan dengan plot berwarna merah memiliki probabilitas untuk tidak mengalami kambuh pertama kali selama dua tahun lebih tinggi daripada pasien yang mengidap kanker serviks sebagai penyakit utama. Namun pada kurva kedua kelompok tersebut masih memiliki probabilitas di bawah 50\%. Selain itu, setelah dua bulan pertama pasien kanker serviks sebagai penyakit utama cenderung mengalami penurunan kondisi apabila dibandingkan dengan pasien dengan kanker serviks sebagai penyakit penyerta.

5) Faktor Status Anemia

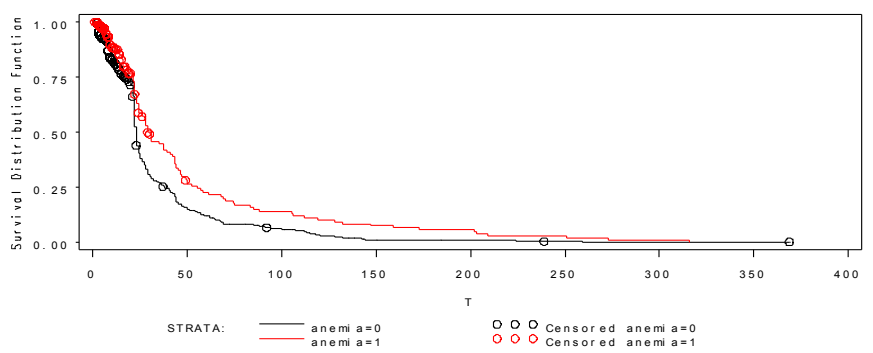

Gambar 6. Kurva Survival Faktor Status Anemia.
Gambar tersebut dapat dilihat bahwa probabilitas pasien kanker serviks yang mengalami anemia memiliki probabilitas yang lebih tinggi untuk tidak mengalami kambuh pertama kali dari pada pasien kanker serviks yang tidak mengalami anemia. Kurva tersebut tidak sesuai didalam medis bahwa pasien kanker serviks yang mengalami anemia memiliki resiko lebih tinggi untuk kambuh daripada pasien kanker serviks yang tidak mengalami anemia. Probabilitas kedua kelompok masih sama yaitu dibawah 50\% hingga akhir pengamatan.

\section{6) Faktor Status Operasi}

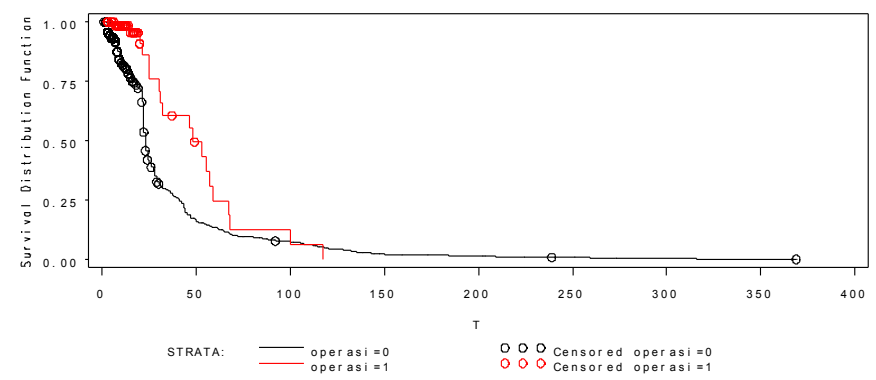

Gambar 7. Kurva Survival Faktor Status Operasi.

Berdasarkan faktor operasi menunjukkan bahwa pasien yang melakukan tindakan operasi memiliki probabilitas tidak kambuh yang lebih besar daripada pasien yang tidak melakukan operasi. Probabilitas tidak kambuh pada pasien yang melakukan operasi diatas 0,5 namun setelahnya menurun hingga penelitian berakhir. Sedangkan probabilitas pasien yang tidak melakukan operasi dibawah 0,5 artinya setelah bulan kedua pasien kanker serviks yang tidak melakukan operasi cenderung lebih beresiko untuk mengalami penurunan kondisi.

Perbedaan atau tidak adanya perbedaan dari kurva survival kelompok pasien kanker serviks berdasarkan faktor yang diduga mempengaruhi kekambuhan pasien kanker serviks digunakan uji Log-Rank. Hasil uji Log-Rank ditunjukan pada tabel sebagai berikut

Tabel 2.

Uji Log-Rank

\begin{tabular}{lcccc}
\hline \hline \multicolumn{1}{c}{ Variabel } & Log-Rank & $D f$ & $p$-Value & Keputusan \\
\hline Usia & 0,0461 & 1 & 0,83 & Gagal Tolak $\mathrm{H}_{0}$ \\
Kemoterapi & 14,001 & 1 & 0,2367 & Gagal Tolak $\mathrm{H}_{0}$ \\
Komplikasi & 0,1439 & 1 & 0,7045 & Gagal Tolak $\mathrm{H}_{0}$ \\
Penyakit Penyerta & 211,359 & 1 & $<0,0001$ & Tolak $\mathrm{H}_{0}$ \\
Status Anemia & 17,293 & 1 & $<0,0001$ & Tolak $\mathrm{H}_{0}$ \\
Status Operasi & 107,729 & 1 & 0,001 & Tolak $\mathrm{H}_{0}$ \\
\hline \hline
\end{tabular}

Berdasarkan tabel diatas dapat diketahui hasil uji Log-Rank kelompok kanker serviks dari keenam faktor. Nilai uji LogRank yang diperoleh nilai $p$-value yang nilainya kurang dari $\alpha=0,05$ yaitu pada faktor penyakit penyerta, status anemia dan status operasi maka keputusan yang dihasilkan adalah tolak $\mathrm{H}_{0}$ sehingga dapat disimpulkan bahwa terdapat perbedaan antara kurva survival paada ketiga faktor tersebut.

\section{B. Pengujian Asumsi Proportional Hazard}

1) Metode Goodness of Fit

Pengujian asumsi dengan metode goodness of fit merupakan pendekatan yang digunakan untuk memperkuat keputusan 
pemenuhan asumsi setelah menggunakan metode grafik. Berikut merupakan tabel goodness of fit untuk setiap faktor yang diduga mempengaruhi kekambuhan pasien kanker serviks.

Tabel 3.

Uji Asumsi Proportional Hazard Metode Goodness Of Fit

\begin{tabular}{lccc}
\hline \hline \multicolumn{1}{c}{ Variabel } & Korelasi & $p$-Value & Keputusan \\
\hline Usia & 0,07009 & 0,0700 & Gagal Tolak $\mathrm{H}_{0}$ \\
Kemoterapi & $-0,05845$ & 0,1310 & Gagal Tolak $\mathrm{H}_{0}$ \\
Komplikasi & 0,03459 & 0,3717 & Gagal Tolak $\mathrm{H}_{0}$ \\
Penyakit Penyerta & 0,03450 & 0,3729 & Gagal Tolak $\mathrm{H}_{0}$ \\
Status Anemia & 0,02840 & 0,4633 & Gagal Tolak $\mathrm{H}_{0}$ \\
Status Operasi & 0,13923 & 0,0003 & Tolak $\mathrm{H}_{0}$ \\
\hline \hline
\end{tabular}

Berdasarkan tabel diatas dapat diketahui bahwa pada faktor status operasi memiliki nilai korelasi yang tinggi dengan waktu survival. Jika $\alpha$ yang digunakan sebesar 0,05 keputusan yang diperoleh adalah tolak $\mathrm{H}_{0}$ sehingga dapat disimpulkan bahwa variabel status operasi tidak memenuhi asumsi proportional hazard. Pada kasus ini metode regresi Cox Proportional Hazard tidak dapat digunakan karena terdapat salah satu faktor yang tidak memenuhi asumsi proportional hazard yang menunjukkan bahwa status operasi pasien kanker serviks di RSUD dr. Soetomo Surabaya memiliki probabilitas untuk kambuh yang bergantung pada waktu.

2) Metode Time Dependent

Tabel 4.

Uji Asumsi Proportional Hazard Metode Time Dependent

\begin{tabular}{lccc}
\hline \multicolumn{1}{c}{ Variabel } & $W^{2}$ & $p$-Value & Keputusan \\
\hline Usia & 2,3553 & 0,1249 & Gagal Tolak $\mathrm{H}_{0}$ \\
Kemoterapi & 3,4464 & 0,0634 & Gagal Tolak $\mathrm{H}_{0}$ \\
Komplikasi & 2,2819 & 0,1309 & Gagal Tolak $\mathrm{H}_{0}$ \\
Penyakit Penyerta & 1,6453 & 0,1996 & Gagal Tolak $\mathrm{H}_{0}$ \\
Status Anemia & 0,9433 & 0,3314 & Gagal Tolak $\mathrm{H}_{0}$ \\
Status Operasi & 12,7613 & 0,0004 & Tolak $\mathrm{H}_{0}$ \\
\hline \hline
\end{tabular}

Berdasarkan tabel diatas merupakan hasil dari uji asumsi proportional hazard menggunakan variabel time dependent. Fungsi waktu yang digunakan adalah $\ln (T)$, jika $\alpha$ yang digunakan sebesar 0,05 maka faktor status operasi pasien kanker serviks memiliki keputusan tolak $\mathrm{H}_{0}$ sehingga variabel tersebut tidak memenuhi asumsi proportional hazard. Hasil pengujian asumsi menggunakan variabel time dependent mampu memperkuat hasil dari pengujian asumsi menggunakan goodness of fit sehingga dapat disimpulkan bahwa faktor status operasi tidak memenuhi asumsi proportional hazard dan dalam penelitian ini tidak dapat menggunakan metode regresi cox proportional hazard.

\section{Pembentukan Model Cox Extended}

Metode alternatif jika asumsi proportional hazard tidak terpenuhi adalah menggunakan regresi cox extended. Variabel status operasi yang diduga mempengaruhi kekambuhan pasien kanker serviks di RSUD dr. Soetomo Surabaya tidak memenuhi asumsi proportional hazard sehingga perlu diinteraksikan terhadap waktu. Interaksi dapat dilakukan dengan dua cara yaitu dengan fungsi waktu dan fungsi Heaviside.

\section{1) Fungsi Waktu}

Tabel 5.

Estimasi Parameter Model Cox Extended dengan Fungsi Waktu

\begin{tabular}{lccc}
\hline \hline \multicolumn{1}{c}{ Variabel } & $\begin{array}{c}\text { Estimasi } \\
\text { Parameter }\end{array}$ & $\begin{array}{c}\text { Chi- } \\
\text { Square }\end{array}$ & p-Value \\
\hline Usia & 0,004 & 0,819 & 0,365 \\
Kemoterapi & 0,018 & 0,051 & 0,821 \\
Komplikasi & 0,304 & 0,842 & 0,359 \\
Penyakit Penyerta & $-0,201$ & 2,305 & 0,129 \\
Status Anemia & $-0,258$ & 2,745 & 0,098 \\
Status Operasi & $-5,017$ & 13,958 & 0,0002 \\
Status Operasi $\times \ln (T)$ & 1,307 & 12,761 & 0,0004 \\
Likelihood Ratio & & 51,743 & $<0,0001$ \\
\hline \hline
\end{tabular}

Sehingga model yang didapatkan berdasarkan tabel diatas adalah sebagai berikut

$$
\begin{aligned}
\hat{h}(t, x(t))= & \hat{h}_{0}(t) \exp [0,004 \text { Usia }+0,018 \text { Kemoterapi } \\
& +0,304 \text { Komplikasi } \\
& -0,201 \text { Penyakit Penyerta } \\
& -0,258 \text { Status Anemia } \\
& -5,017 \text { Status Operasi } \\
& +1,307(\text { Status Operasi } \times \ln (T)]
\end{aligned}
$$

Berdasarkan tabel variabel yang memiliki $p$-value kurang dari $\alpha$ sebesar 0,05 adalah variabel status operasi dan Status Operasi $\times \ln (T)$. Sehingga kedua faktor tersebut berpengaruh signifikan terhadap kekambuhan pasien kanker serviks di RSUD dr. Soetomo Surabaya. Selanjutnya adalah mengeluarkan variabel yang tidak signifikan dari model dan melakukan estimasi parameter model cox extended yang telah signifikan dengan interaksi fungsi waktu.

Tabel 6.

Estimasi Parameter Model Cox Extended dengan Fungsi Waktu Variabel yang Signifikan

\begin{tabular}{cccc}
\hline \hline Variabel & Estimasi Parameter & $W^{2}$ & $p$-Value \\
\hline Status Operasi & $-5,222$ & 14,534 & 0,0001 \\
Status Operasi $\times \ln (T)$ & 1,363 & 13,339 & 0,0003 \\
Likelihood Ratio & & 29,359 & $<0,0001$ \\
\hline \hline
\end{tabular}

Dari tabel diatas dapat dibentuk model baru berdasarkan variabel yang signifikan mempengaruhi kekambuhan pasien kanker serviks yaitu sebagai berikut.

$$
\begin{aligned}
\hat{h}(t, \boldsymbol{x}(t))=\hat{h}_{0}(t) & \exp [-5,222 \text { Status Operasi } \\
& +1,363(\text { Status Operasi } \times \ln (T)]
\end{aligned}
$$

Nilai hazard ratio dapat diketahui dengan permisalan waktu karena variabel status operasi berubah-ubah dan bergantung pada waktu. Berikut merupakan nilai hazard ratio berdasarkan variabel status operasi pada waktu-waktu tertentu.

Tabel 7.

Hazard Ratio Model Cox Extended dengan Fungsi Waktu

\begin{tabular}{cc} 
Waktu (Hari) & Hazard Ratio $(\widehat{H R})$ \\
7 & 0,076 \\
46 & 0,996 \\
117 & 3,556 \\
\hline
\end{tabular}


Dari tabel diatas dapat dilihat bahwa semakin lama pasien kanker serviks di RSUD dr. Soetomo Surabaya tidak mengalami kambuh setelah melakukan tindakan operasi maka semakin besar laju kekambuhan pertama kali pasien kanker serviks. Pasien yang tidak mengalami kambuh selama 117 hari setelah melakukan operasi memiliki laju kekambuhan sebesar 3,556 kali lebih besar daripada yang tidak melakukan tindakan operasi. Hal tersebut disebabkan oleh keberhasilan tindakan operasi yang dilakukan pada pasien kanker serviks di RSUD dr. Soetomo Surabaya sehingga mampu bertahan untuk tidak mengalami kambuh.

\section{2) Fungsi Heaviside}

Hazard ratio sebelum hari ke-40 dicurigai berbeda dengan hazard ratio setelah hari ke-40 sehingga digunakan fungsi heaviside sebagai berikut

$$
\begin{gathered}
g(t)=\left\{\begin{array}{l}
1 \text { jika } T<40 \text { hari } \\
0 \text { jika } T \geq 40 \text { hari }
\end{array}\right. \\
\text { Tabel } 8 .
\end{gathered}
$$

Estimasi Parameter Model Cox Extended dengan Fungsi Heaviside

\begin{tabular}{lccc}
\hline \hline \multicolumn{1}{c}{ Variabel } & Estimasi Parameter & Chi-Square & $p$-value \\
\hline Usia & 0,004 & 0,947 & 0,330 \\
Kemoterapi & 0,016 & 0,045 & 0,831 \\
Komplikasi & 0,299 & 0,821 & 0,364 \\
Penyakit Penyerta & $-0,201$ & 2,319 & 0,127 \\
Status Anemia & $-0,260$ & 2,811 & 0,093 \\
Status Operasi $\times \mathrm{g}(t)$ & $-1,222$ & 12,982 & 0,000 \\
Status Operasi $\times \mathrm{g}(t)$ & 0,333 & 0,478 & 0,489 \\
Likelihood Ratio & & 44,691 & $<0,0001$ \\
\hline \hline
\end{tabular}

Model cox extended kekambuhan pasien kanker serviks dengan fungsi heaviside adalah sebagai berikut

$$
\begin{aligned}
\hat{h}(t, x(t))=\hat{h}_{0}(t) & \exp [0,004 \text { Usia }+0,016 \text { Kemoterapi } \\
& +0,299 \text { Komplikasi } \\
& -0,201 \text { Penyakit Penyerta } \\
& -0,260 \text { Status Anemia } \\
& -1,222(\text { Status Operasi } \times g(t)) \\
& +0,333(\text { Status Operasi } \times g(t))]
\end{aligned}
$$

Dari tabel tersebut dapat diketahui bahwa variabel yang berpengaruh signifikan terhadap kekambuhan pasien kanker

\begin{tabular}{|c|c|c|c|}
\hline Variabel & Estimasi Parameter & $\begin{array}{c}\text { Chi- } \\
\text { Square }\end{array}$ & $p$-Value \\
\hline Status Operasi $\times \mathrm{g}(t)$ & $-1,251$ & 13,826 & 0,0002 \\
\hline Likelihood Ratio & & 21,353 & $<0,000$ \\
\hline
\end{tabular}
serviks di RSUD dr. Soetomo Surabaya adalah status anemia dan status operasi $\times g(t)$. Selanjutnya dilakukan pembentukan model baru cox extended yang melibatkan variabel yang telah signifikan yaitu sebagai berikut.

Tabel 9.

Estimasi Parameter Model Cox Extended dengan Fungsi Heaviside Variabel yang Signifikan

Berikut merupakan model cox extended baru yang terdiri atas variabel yang signifikan mempengaruhi kekambuhan pasien kanker serviks

$$
\hat{h}(t, x(t))=\hat{h}_{0}(t) \exp [-1,251(\text { Status Operasi } \times \mathrm{g}(t)]
$$

Pengaruh dari setiap variabel tersebut dapat diketahui dengan menghitung nilai dari hazard ratio dari variabel yang signifikan ditunjukkan pada tabel berikut.

Tabel 10.

Hazard Ratio Model Cox Extended dengan Fungsi Heaviside Variabel Hazard Ratio $(\widehat{H R})$

Status Operasi $\times g(t) \quad 0,286$

Berdasarkan tabel diatas diketahui pasien kanker serviks yang melakukan tindakan operasi sebelum hari ke-40 memiliki laju untuk kambuh 0,282 lebih kecil daripada yang tidak melakukan tindakan operasi.

\section{Pemilihan Model Cox Terbaik}

Berikut merupakan perbandingan model terbaik berdasarkan kriteria AIC.

Tabel 11.

Nilai AIC Model Cox Extended dengan Fungsi Waktu dan Fungsi Heaviside

\begin{tabular}{cc}
\hline \hline Model Cox Extended & Nilai AIC \\
\hline Fungsi Waktu & 7533.342 \\
Fungsi Heaviside & 7539,347 \\
\hline \hline
\end{tabular}

Model dari cox extended terbaik dilihat berdasarkan kriteria nilai AIC terkecil. Berdasarkan tabel diatas nilai AIC pada model cox extended menggunakan fungsi waktu lebih kecil daripada model cox extended menggunakan fungsi heaviside. Sehingga kesimpulan model terbaik yang dapat digunakan untuk memodelkan kekambuhan pasien kanker serviks di RSUD dr. Soetomo Surabaya adalah model cox extended menggunakan fungsi waktu.

\section{KESIMPULAN DAN SARAN}

Kurva survival Kaplan-Meier dari keenam faktor yang diduga mempengaruhi kekambuhan pasien kanker serviks menunjukkan bahwa probabilitas pasien kanker serviks mengalami tidak kambuh pertama kali selama 2 tahun cenderung rendah yaitu dibawah $50 \%$ pada dua bulan pertama dan dilanjutkan dengan kondisi pasien yang cenderung mengalami penurunan. Variabel status operasi tidak memenuhi asumsi proportional hazard sehingga metode yang digunakan untuk memodelkan kekambuhan pasien kanker serviks adalah metode regresi cox extended. Model cox extended terbaik yaitu dengan menggunakan fungsi waktu berdasarkan kriteria nilai AIC terkecil. Variabel yang signifikan berpengaruh terhadap model adalah status operasi. Pasien kanker serviks yang melakukan tindakan operasi memiliki laju untuk mengalami kambuh yang berbeda-beda karena bergantung pada waktu.

Saran yang diberikan untuk penelitian selanjutnya adalah lebih baik menggunakan variabel stadium dan variabel penting lainnya karena diduga faktor tersebut berpengaruh terhadap pemodelan kekambuhan pasien kanker serviks

\section{DAFTAR PUSTAKA}

[1] WHO (World Health Organization). (2013). Comprehensive Cervical Cancer Prevention and Control: a Healhier Future for Girls and Women. WHO Guidance Note, 1-12. 
[2] Yayasan Kanker Indonesia. (2013). Press Release Training of Trainers Pap Tes dan IVA Serviks.

[3] International Agency for Research on Cancer. (2015). IARC Handbooks of Cancer Prevention Vol 10: Cervix Cancer Screening. France: IARC Press.International Agnecy for Research on Cancer. (2005). IARC Handbooks of Cancer Prevention Vol 10 : Cervix Cancer Screening. Prancis: IARC press.

[4] Gayatri, D. (2002). Hubungan Stadium dengan Ketahanan Hidup 5tahun Pasien Kanker Serviks di RSUPN Cipto Mangun Kusumo dan RSK Dharmais. Jakarta: Tesis UI..

[5] Sirait, A. M., Ryadina, W., \& Sihombing, M. (2004). Survival Kanker Serviks di RS dr. Kariadi Semarang. Jurnal Kedokteran Media Medika Indonesiana FK UNDIP.0.

[6] Wijayanti, R. (2014). Perbandingan Analisis Regresi Cox dan Analisis Survival Bayesian pada Ketahanan Hidup Kanker Serviks di RSUD Dr. Soetomo Surabaya. Tesis ITS .

[7] Inayati, K. (2015). Analisis Survival pada Pasien Kanker Serviks di RSUD dr. Soetomo Surabaya Menggunakan Model Cox Stratifikasi. Surabaya: Tugas Akhir ITS.Kleinbaum, D. G., \& Klein, M. (2012).
Survival Analysis A Self-Learning Text Third Edition. Newyork: Springer.

[8] Aini, I. N. (2011). Extended Cox Model untuk Time Independent Covariate yang Tidak Memenuhi Asumsi Proportional Hazard Pada Model Cox Proportional Hazard. Skripsi Universitas Indonesia .

[9] Afifah, A. (2016). Regresi Cox Extended untuk Memodelkan Ketahanan hidup Pasien Kanker Serviks di RSUD dr. Soetomo Surabaya. Surabaya: TA ITS.Datta, M. (2010). Rujukan Cepat Obstetri \& Ginekologi. Jakarta : EGC.

[10] Kleinbaum, D. G., \& Klein, M. (2012). Survival Analysis A Self Learing Text Third Edition. New York: SpringerAmerican Cancer Society. (2014). Cancer Facts in Medical Research. Atlanta: American Cancer Society.

[11] American Cancer Society. (2013). Cancer Facts in Medical Reseach. Atlanta: American Cancer Society.

[12] Diananda, R. (2007). Mengenal Seluk Beluk Kanker. Yogyakarta: Katahati.

[13] Iskandar, J. (2007). Kanker. Jakarta: PT. Bhuana Ilmu Populer.

[14] Hendry, d. (2007). Penuntun Pelayanan Pendidikan Penelitian Bagian Obstetri Ginekologi. Jakarta: FKUI. 